This is a self-archived version of an original article. This version may differ from the original in pagination and typographic details.

Author(s): Horsti, Karina

Title: Digital materialities in the diasporic mourning of migrant death

Year: 2019

Version: Accepted version (Final draft)

Copyright: @ 2019 SAGE Publications

Rights: In Copyright

Rights url: http://rightsstatements.org/page//nC/1.0/?language=en

Please cite the original version:

Horsti, K. (2019). Digital materialities in the diasporic mourning of migrant death. European Journal of Communication, 34(6), 671-681. https://doi.org/10.1177/0267323119886169 


\title{
Digital materialities in the diasporic mourning of migrant death
}

\author{
Karina Horsti \\ Academy of Finland Fellow \\ Department of Social Sciences and Philosophy \\ University of Jyvaskyla, Finland \\ Karina.horsti@jyu.fi
}

\begin{abstract}
This article examines memorialization among the family and friends of those who have died at the world's deadliest border in the Mediterranean Sea. Digital media platforms are central spaces for new, innovative forms of coping with ambiguous loss or the inability to mourn over a dead body. The analysis focuses on the role of digital media technologies and the relationship between digital and material elements in memorialization. I examine the creation and circulation of digital objects of memorialization: visual assemblages in which the material and digital intertwine. The analysis demonstrates that digital media practices are not separate from the material world, nor do they make mourning and memorializing less human or less authentic. On the contrary, in transnational and mobile circumstances, digital technologies facilitate human, ethical engagement with complicated grief. Memorializing is crucial for both the private and the public lives of diasporic communities. In Europe, public recognition of the memorialization of refugee deaths would increase understanding of the human consequences of the border, allowing the dead to be seen as individuals with human relationships rather than as numbers.
\end{abstract}

Introduction

The Mediterranean Sea is the deadliest border zone in the world: the International Organization for Migration (IOM) estimates there have been more than 18,000 migrant deaths in 2014-2018 (IOM 2019, see also United for Intercultural Action 2019). Most of the bodies disappear into the sea or are buried in anonymous graves at cemeteries on either side of the EU border. Forensic identification of the migrant dead is very limited in countries bordering the Mediterranean Sea (Ben Attia et al. 2016; Kovras and Robins 2016). For example, in the case of the 3 October 2013 shipwreck in Lampedusa, Italian authorities retrieved 368 bodies, of which only 40 had been officially identified as of 2019 (Cattaneo interview in Fioravanti 2019). Mourning rituals such as funerals are crucial markers of transition with significance for both personal and social lives. Without such transitions, living with the loss becomes difficult (Robins 2019: 8).

In recent years, scholars have examined the mourning of border deaths in Europe by focusing on activists and artists (Horsti 2016; Stierl 2016; Rygiel, 2016; Stümer 2018), local communities (Puggioni 2015; Zagaria 2016; Horsti and Neumann 2018; Mirto et al. 2019), and European authorities (Gatta 2014; Ritaine 2016). This work often builds on Judith Butler's notion of 'ungrievability' (Butler 2009) and critiques Europeans' inability to respond ethically to migrant 
death as a social loss worthy of common grief. Nevertheless, within the growing literature on migrant deaths at the European border (see also Brian and Laczko 2016; Kovras and Robins 2016; Robins 2019; Albahari 2015, 2016; Squire 2016), the issue of how families and diasporic communities mourn and cope with loss needs more attention.

This paper draws on material collected during my research on the afterlife of the 3 October 2013 migrant shipwreck in Lampedusa, Italy, in which 368 refugees, primarily Eritreans, died; 155 survived. This multisited and multimethod research project, which has taken place in 2014-2019, has included ethnographic research in Lampedusa during anniversary commemorations and among survivors and family members in Sweden, visual and textual analysis of mainstream and social media materials related to the disaster, and interviews and co-analysis sessions with survivors and Eritrean human rights activists. I have collaborated regularly with a group of ten survivors of the disaster and with three family members of victims. The research for this paper includes an analysis of the victims' graves in Sicilian cemeteries, interviews with and observations of Sicilian locals, and interviews and collaborative analysis with two survivors, Aregai Mehari and Solomon Ghebrihiwet, and one family member of a victim, Adal Neguse. ${ }^{1}$ The new forms of memorializing discussed in this paper demand of researchers an attention to detail and to particularities, which can be accomplished only by listening to and spending time with those who are most affected by the deadly border.

My research on the memorialization of border deaths has shown that digital media platforms are central spaces for new, innovative forms of memorialization and for coping with death or disappearance in the EU border zone and the inaccessibility of dead bodies and gravesites. ${ }^{2}$ Social media platforms and mobile technologies have allowed families and mourning communities to connect over long distances and difficult-to-cross borders. For example, people in the diasporic community have created digital mediated memorials on YouTube and Facebook to console friends and family. The memorials may combine music, digitized photographs, news images and verses from the Bible or the Qur'an. These online memorials are accessible across borders and in some ways stand in for the victims' unknown or inaccessible graves. Digitally mediated memorials blur the boundaries of public and private, local and global, planned and spontaneous, and formal and vernacular memorialization. These media practices are part of the transformation that the emergence of digital technologies has brought about in transnational relationships more broadly. Scholars of media and migration have observed, for example, that digital technologies are used to create co-presence and maintain transnational relationships (Baldassar 2008; Madianou 2016; Wilding 2018: 120 - 122, 130; about media in long-distance relationships, see also Goggin and Hjorth 2009; Hjorth and Pink 2014; Pink and Fors 2017).

This article builds on these observations regarding digital technologies and the personal and social importance of mourning and memorializing border deaths. It adds to my previous work by examining in detail the relationship between the digital and material aspects of memorialization. I examine memorialization from the perspective of survivors and the relatives of the victims. Such refugee-centred analysis of the memorialization of border deaths shifts the attention beyond Europeans' commemorative performances to acknowledging the creative agency, hopes and

\footnotetext{
${ }^{1}$ I would like to thank Adal Neguse for his invaluable research assistance and Aregai Mehari and Solomon Ghebrihiwet for collaborating in the analysis and sharing their experiences.

${ }^{2}$ See Horsti 2017, 2019, forthcoming.
} 
politics of refugees (see Espiritu 2014:13). I ask how and why mourners use both digital and material elements as they memorialize and how they transform the material into the digital and the digital into the material. ${ }^{3}$ How do the digital and the material become entangled in the mourning of border deaths? What is the meaning of such memory work and how does it connect people across distances? Finally, the paper argues for public recognition of refugee and migrant communities' practices of memorializing border deaths, which would increase understanding of the human consequences of border deaths in European societies. Recognition of border deaths as a common loss and of the dead as individuals who mattered to society are necessary for the creation of a self-reflexive, inclusive and convivial Europe.

Tracing a photograph

As I looked through the photographs of migrant graves that I had taken in Sicilian cemeteries in October 2018, one photo gave me pause: there was something familiar in the framed photograph of a woman and a boy that had been placed inside a Sicilian family tomb. ${ }^{4}$ The cemetery caretaker had directed me to the tomb when I had asked if he knew where the victims of Strage di Lampedusa, 'the Massacre of Lampedusa', as some Italians call it, were buried. Whereas most of the migrant graves in Sicily were marked only by a number and had no signs of memorialization, in this case, a Sicilian family had 'adopted' two migrant bodies and buried them in their family tomb.

The Sicilian family name was formed from handmade iron letters next to the tomb's brassframed glass doors, through which I had taken the picture of the framed photograph. On a small marble surface inside, next to a framed photograph of an elderly Sicilian couple, is a studio photograph of two Eritreans, a young smiling woman and a boy about five years old. She wears jeans and an orange T-shirt, and her hair is pulled into a ponytail. The boy is dressed in a white short-sleeved shirt and jeans. The studio backdrop features a barn and a sandy yard. Beside the photograph in the tomb was a teddy bear in a striped outfit with a red heart on it. It was the same teddy bear that had been placed on each of the child victims' coffins, as was seen in the news photographs taken in Lampedusa on 9 October 2013 when the mayor of Lampedusa, Giusi Nicolini, Italian Prime Minister Enrico Letta, and European leaders Cecilia Malmström and José Barroso paid their respects to the dead migrants.

Where had I seen that photograph before? I searched through the Facebook pages of the survivors with whom I was in touch. Many of them now lived in Sweden or Norway as refugees. Five years after the disaster, many still had something related to Lampedusa as a Facebook profile or cover photo: pictures in which they posed with their Lampedusan civilian rescuers or with brothers, sisters, cousins or friends when they were still alive, or pictures of the dead before they were killed - similar to the photograph inside the Sicilian tomb. Finally, I found the photograph on the Facebook page of Solomon Ghebrihiwet, one of the survivors with whom I

\footnotetext{
${ }^{3}$ Jonathan Ong and Mirca Madianou have discussed the relationship between digital and material manifestations in mourning in disaster-affected communities after Typhoon Haiyan in the Philippines. I would like to acknowledge their presentation "WWe hope they might reply to us one day": Coping with extreme loss through social media in the aftermath of disaster', at the ICA conference, June 13, 2016, in Fukuoka, Japan.

${ }^{4}$ Details about the location have been omitted to protect the privacy of the families.
} 
had collaborated on a research project. Ghebrihiwet is in his twenties and has resettled in a small town in Sweden, where he works as a bus driver.

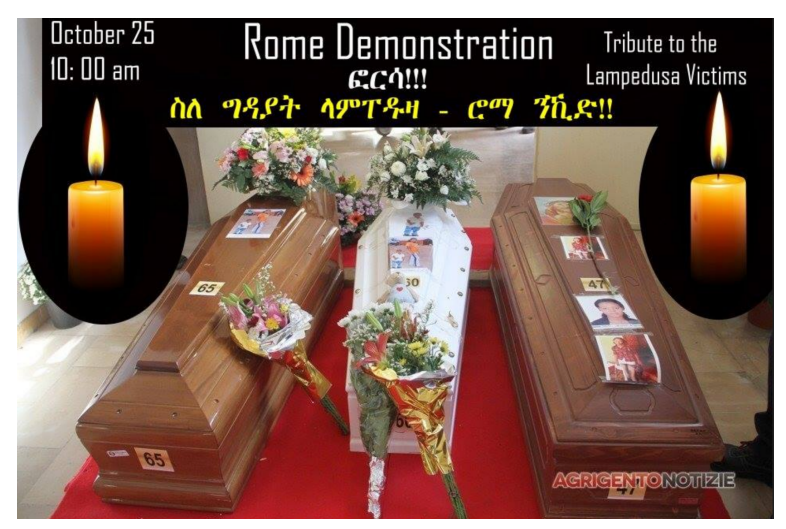

Image 1: Digital invitation to a memorial and demonstration in Rome, circulated on Eritrean online platforms in 2013. A similar design using the same photograph appeared earlier in an Eritrean diasporic invitation to the Italian state funeral for Lampedusa disaster victims.

The photograph I was looking for was part of a digital collage that Ghebrihiwet was using as a cover photo. There are three coffins in the main image: two brown adult-sized ones, and between them, a white small one. Round images of burning candles have been added to either side of the picture. The collage is a digital invitation to a memorial for the victims of the Lampedusa disaster and a demonstration against the Eritrean regime that the Eritrean diasporic community in Rome held on 25 October 2013. The photograph of the woman and the boy had been taped to the child's coffin above the number indicating the order in which the bodies had been recovered from the sea. The teddy bear is also visible on top of the coffin.

I sent Ghebrihiwet the photographs I had taken in the Sicilian cemetery. He responded that he had also visited that grave, with the pictured woman's brother, who lives in Norway. The woman and her son had been fleeing Eritrea to Norway, where her brother would have helped them start a new life. I asked if they had given the photograph to the Sicilian family that had adopted and buried the woman and her son, but he said they had not been successful in their attempts to contact them. They had located the grave by looking for the serial numbers on the coffins, and like me, had seen the framed photograph inside. It had ended up there with the coffin it had been attached to. The photograph had originated with the woman's brother, who had printed it when he had come to Lampedusa from Norway to search for his sister immediately after the disaster. Ghebrihiwet had come to know the woman and her son during their journey through Sudan, the Sahara and Libya. He had protected them by posing as her husband. The photograph in the tomb was the same they had attached to the boy's coffin in 2013 when they had mourned the dead at the Lampedusa harbour before the authorities transported the coffins to Sicily on Italian naval ships.

Documenting the materiality of memorializing

As a response to my inquiry about the grave in Sicily Solomon Ghebrihiwet sent me ten pictures via Facebook Messenger depicting the scene of vernacular memorialization that took place at the 
Lampedusa harbour in 2013. The ceremony and the loading of the coffins onto the ships had lasted for hours: some of the photos were taken in daylight, others when it was already dark. The images revealed a contrast between the grief and intimacy of the survivors and relatives of the victims on the one hand, and the undignified treatment of the coffins as they were moved to the ships by a crane on the other. The coffins of the woman and the boy were strapped onto separate pallets. Solomon and the brother personalized the boy's coffin with flowers, the teddy bear and two pictures - the photograph that the Sicilian family later framed, ${ }^{5}$ and an enlarged photograph of the boy. On the woman's coffin, they placed a larger version of the studio portrait and below the picture added the victims' names, birth dates and 'Lampedusa 3-10-2013'. The packing tape they used to secure the images reached from one side of the coffin to the other, and was applied in several layers. They wanted to ensure that the pictures would stay affixed to the coffins during their journey - at the time, they had no idea where they would end up. The ten pictures I was sent depicted the different phases of the scene at the dock: Solomon Ghebrihiwet stands next to the woman's coffin and holds a roll of packing tape in one hand and a photograph in the other. He kneels down beside the boy's coffin and kisses the photograph taped to it. He holds the brother's arm while the brother dries his tears. To the side, a woman cries and another relative films the mourners with his phone; behind them, a European - perhaps a tourist or a humanitarian worker - films the scene.

These pictures of memorializing were meaningful for Ghebrihiwet: he still had them on his phone five years after the disaster and was eager to share them with me. Ghebrihiwet and the woman's brother had documented the scene at the harbour carefully so that other relatives and friends would be able to see how they had memorialized the dead. The death of the woman and her son were made visible through two kinds of photographs: the studio portraits attached to the coffins and the photographs depicting the personalized coffins. The sociality that is an important part of mourning was both mediated and produced through digital technology. However, the temporality of the mediation was focused on the future rather than the present. Rather than livestreaming the ritual, the vernacular funeral was recreated through photographs, which were shared among friends and family on Viber and Facebook Messenger, where they could be retrieved over and over again. The objective was therefore archiving and documenting: allowing mourners to relive the ritual at any time and in any place by swiping through or printing the photographs. The photographs of the rituals at the Lampedusa harbour and the material signs of mourning attached to the coffins were compelling precisely because they documented the act of mourning for those who were not present at the time. Sharing the photos with family and friends across the Eritrean diaspora in Europe, Ethiopia and beyond, and with the relatives who remained in Eritrea was a means to create a community of mourners across distances.

Those who lost loved ones in the Lampedusa disaster, considered themselves 'lucky' because they were able to mourn in the presence of the bodies and the graves. More typical among the Eritrean community is that relatives have to deal with ambiguous losses or the inaccessibility of graves. Uncertainty about death can have severe consequences for the family and friends of the disappeared (Robins 2019: 2). The uncertainty can haunt relatives for years and prevent them from living on - in legal, social and psychological terms. Many of the families of those who have perished deal with ambiguous loss (Boss 1999, 2004; Robins 2014) - a condition of uncertainty in which a person is simultaneously 'there' and 'not there' (Boss 1999: 6). In such circumstances,

\footnotetext{
${ }^{5} \mathrm{I}$ am not sure if it is the exact same print or a photograph of the photograph.
} 
people tend to believe whatever is most favourable for them. For example, mothers of disappeared Tunisian migrants tend to rely on the affective and sensory over rational explanations and believe that their sons are alive (Robins 2019: 10; Ben Attia et al 2016). Even in cases of known deaths, families are often unable to mourn together, repatriate the body or gain access to the grave, and therefore unable to bring personal and social closure to their relationships.

The deaths of the woman and her son were certain for Ghebrihiwet and the woman's brother, leading them to take up the responsibility of mediating that certainty to the victims' family and friends. Creating a visual archive of the vernacular funeral in Lampedusa communicated that knowledge to others and shared their ritual of closure. By documenting the ritual, they were able to prevent the kinds of complicated emotions that are typical for transnational families in situations of ambiguous loss.

\section{Recognition of migrant memorialization}

Though Solomon Ghebrihiwet had taken several photographs of the personalized coffins of the woman and her son, he had not selected any of those photos as his Facebook cover image. Instead, he had posted the invitation to the demonstration, which featured a different photograph of the two coffins he had decorated arranged beside a third coffin. The photograph used in the invitation originated from the Sicilian online news site Agrigento Notizie (the site's logo was left untouched). The image is no longer available in the site's online archive, but it most likely appeared in the local news section covering the arrival of the 368 coffins in Agrigento to be buried in Sicilian cemeteries. The news image was repurposed as an invitation to a demonstration by pasting round images of burning candles on either side and adding the text 'Tribute to the Lampedusa victims' in English. With these changes, the organizers transformed the digital news photograph into a digital memory object. By posting the invitation on his own Facebook page, Ghebrihiwet honoured the memory work carried out by others. He also communicated to Facebook friends that the memorialization he had performed with the woman's brother had been recognized by others - both Agrigento Notizie and the Eritrean diaspora in Rome. In addition, it was a political statement: the event in Rome was not only a memorial but also a protest against the Eritrean regime. By posting the image in its repurposed form, Ghebrihiwet took a public stance against the regime in Eritrea from which he had fled.

As the arrangement of the three coffins in Agrigento and the photograph in Agrigento Notizie demonstrate, the personalized coffins attracted the attention of the Sicilians on the receiving end of the 368 coffins, most of which were unmarked and anonymous. Unlike the rest of the coffins, the three in the photographed arrangement were 'adopted' by two Sicilian families and interred in their family tombs. Amalia Vullo (interview, 2018), who adopted the female body in the third coffin, explained that she had been working for the municipality of Agrigento when the disaster occurred. She was shocked by the television footage of the coffins being transferred at the Lampedusa harbour for transport to Sicily. For Vullo, the cranes that were used to move the coffins represented inhumanity and ignorance. She then asked to bury one of the dead in her family tomb; she was assigned the body of a woman who had been identified and whose coffin had been personified through photographs of her and a picture of Jesus. The images communicated to the Sicilians not only the dead woman's religion but also her relationality: she 
was missed and being mourned by someone, as evidenced by the personalization of the coffin. Instead of being marked only with a number, like most of the other dead, the decorations represented the woman as a person-as-such, as who she was (Edkins 2011: 7). The photos of the woman, the image of Jesus, and even the deliberative use of thick layers of transparent packing tape communicated the relationality of the dead woman - a central aspect of being human.

\section{Digital objects of memorialization}

There have been at least four different phases in the life of the photograph of the woman and her child as it has travelled and transformed in and through the world in which the digital and the material intertwine. First, there is the studio photograph of the woman. It seems that the woman and the boy were not photographed together; instead, the image seems to have been assembled from two different photographs - the dimensions are awkward. As a genre, studio photography holds specific meanings. Such photos often taken as a future aide-mémoire, a memento. At the same time, it is unclear what the occasion for taking the picture was. Although a memento, it is placeless and timeless. The backdrop adds elements to the subject's environment and alters 'reality': it removes the place and time (such as the season and time of day). By having her photograph taken in a studio, the woman actively participated in making the image: she chose to be photographed, prepared for the photo, and negotiated the pose with the photographer. Importantly, she is conscious of her picture being taken and of how she wants to present herself.

The second phase of the photograph's life takes form when the image is taped to the coffin, its meaning transformed from a memento to a memorial object. The photograph identifies and memorializes the dead and personalizes the coffin. In the third phase, the news photograph of the decorated coffin communicates to the local Agrigento public that the dead were known persons and are missed by someone. Fourth, as the news image was digital, it could easily be captured and reframed. Eritrean diasporic activists used the image in their digital invitations. By adding two burning candles to the image, the news photograph was also repurposed into a digital memorial object. Further, the invitation to the protest reframed the coffins as evidence of the Eritrean regime's human rights violations. The invitation that Solomon Ghebrihiwet added to his Facebook profile was therefore at least three times removed from the original studio photograph of the woman.

Through its four versions, the picture of the woman and her son transformed into a digital object of memorialization. In contexts in which refugees are on the move and families are dispersed over different continents, digitalized photographs are memorial objects that can be distributed transnationally. Survivors can access relevant photographs from online news sites or through their own online archives on social media. The things they had carried with them were lost along the way or at the moment of the disaster, but digital archives allow them access from anywhere to material that can be appropriated and repurposed for memorialization.

These digital objects of memorialization that circulated in Eritrean diasporic online spaces can also rematerialize. At the first anniversary commemoration of the 3 October 2013 disaster in Lampedusa, members of the Italian religious organization Sant'Egidio gave me a postcard featuring a grid of 87 studio photographs of the victims taken in Eritrea or Ethiopia. On the lower right corner of the postcard is the text 3 Ottobre, per non dimenticare (3 October, In 
remembrance) in Italian and Tigrinya. Sant'Egidio was in contact with some surviving family members in Italy, who were themselves in touch with other survivors and relatives elsewhere in Europe. Aregai Mehari, one of the survivors, had created a Facebook group soon after the disaster to stay in touch with the others. One of the group's commemorative practices was to post photographs of the dead from before the disaster. Sant'Egidio had gained access to these photos and printed memorial postcards to be handed out at the commemorative anniversary observances in Lampedusa. A large poster version of the same collage of photos was displayed on the altar at the commemorative mass in Lampedusa's cathedral. Five years later, in October 2018, Sant'Egidio members again disseminated the postcards in Lampedusa, and I noticed that survivors held the cards in their hands when they posed for photos and when they marched in a procession to Porta d'Europa, a memorial sculpture created in remembrance of migrants who have died in the Mediterranean.

These different acts of commemoration exemplify how the digital and the material are deeply entangled ${ }^{6}$ in the cultural practices of memorializing migrant dead. They are particularly relevant in the context of transnational families and people on the move. When tracing the photographs from Lampedusa and observing memorial rituals on- and offline, it has been impossible to distinguish when an object is fully digital or material. Digital materiality is a process that transforms an object according to the needs of those who create and share it. The meaning of digital objects of commemoration emerges in the process of making, sharing and encountering them. Survivors and family members mould and modify material and digital images in a process that communicates their memories of a person and their feelings of loss. These processes of working with digital materiality also create and maintain relationships, such as the relationship between Solomon Ghebrihiwet and the dead woman's brother, and between other geographically distanced relatives and friends. The sharing of such images also reconstitutes the community of survivors and their 'identity of survivorship' - an ethical response to continuing life after witnessing the death of their fellow passengers (Horsti, forthcoming).

In this research it has also proven impossible to distinguish theoretically between an original object and a finished artefact with an aura of authenticity. The sense of materiality is more important than the presence of the original object. These material things such as the paper copies of digitized photographs or the Sant'Egidio postcard became animated and meaningful in the process of commemoration and in the practice of photographing the rituals. They also became meaningful in the connections that emerged when photographs of them were shared digitally with family and friends. Through the sharing of images, the transnational community of mourners was produced.

\section{Conclusions}

Mourning and memorialization are social practices, and digital technologies play an important role in the ways the families and friends of those who have disappeared or died at Europe's borders rework such practices. Ambiguous loss or the inaccessibility of the body or grave forces mourners to create and negotiate new social practices for dealing with death. My analysis has

\footnotetext{
${ }^{6}$ Media anthropologists (e.g. Pink et al. 2016 and Boellstorff 2008) have argued that the digital and the material, or the 'virtual' and the 'real' worlds, are not separate but entangled elements in contemporary everyday lives. The material world is increasingly shaped by digital forms.
} 
demonstrated how digital media practices are not separate from the material world, nor do they make mourning and memorialization less human or less authentic. On the contrary, in the given transnational and mobile circumstances, digital technologies facilitate human and ethical engagement with complicated grief.

In absence of scientific or formal evidence of death, the ability to see and share photographs such as those of the decorated coffins may produce social evidence that can help families to deal with death in situations of ambiguous loss or when the body is inaccessible. While decorating the coffins and documenting the memorialization is meaningful in the private realm, the coffins also took on a public significance. The photograph of the woman and the boy and the three additional versions of it became digital objects of memorialization not only for family members but also for the broader Sicilian and Eritrean diasporic publics.

Finally, the paper has experimented with a refugee-centred perspective and methodology in the analysis of mediated memorializing. In underlining a refugee-centred analytical perspective that highlights the agency of survivors and the relatives of those who have died at the border, I wish not to sentimentalize suffering or the secondary violence related to ambiguous loss and the inaccessibility of graves. My intention is to focus on the ability of those affected by border deaths to create the possibility to live on ethically given the circumstances. This requires research methods that focus on listening to and co-analysing with those who are coping with this struggle.

\section{References}

Albahari, Maurizio (2015) Crimes of Peace: Mediterranean Migrations at the World's Deadliest Border. Philadelphia: University of Pennsylvania Press.

Albahari, Maurizio (2016) 'After the Shipwreck: Mourning and Citizenship in the Mediterranean, Our Sea'. Social Research 83(2): 275-294.

Baldassar, Loretta (2008) 'Missing Kin and Longing to be Together: Emotions and the Construction of Co-presence in Transnational Relationships'. Journal of Intercultural Studies 29(3): 247-266. doi: 10.1080/07256860802169196

Ben Attia, Frida, Tara Brian, Adrian Carrasco Heiermann, Stefanie Grant, Catriona Jarvis, Iosif Kovras, Frank Laczko, Giorgia Mirto, Katerina Polychroni, Simon Robins, Ann Singleton and Amal Shaiah (2016) "Like a Part of a Puzzle Which Is Missing": The Impact on Families of a Relative Missing in Migration across the Mediterranean. Report on the situation of families'. Mediterranean Missing Project. http://openaccess.city.ac.uk/17794/1/Report-on-Families-ofMissing-Migrants.pdf

Boellstorff, Tom (2008) Coming of Age in Second Life. Princeton, N.J.: Princeton University Press. 
Boss, Pauline (1999) Ambiguous Loss: Learning to Live with Unresolved Grief. Cambridge: Harvard University Press.

Boss, Pauline (2004) 'Ambiguous Loss Research, Theory, and Practice: Reflections after 9/11'. Journal of Marriage and Family 66(3): 551-66.

Brian, Tara, and Frank Laczko (eds) (2016) Fatal Journeys: Identification and Tracing of Dead and Missing Migrants. Geneva: IOM.

Butler, Judith (2004) Precarious Life. The Powers of Mourning and Violence. London: Verso.

Butler, Judith (2009) Frames of war: When is life grievable? London: Verso

Edkins, Jenny (2011) Missing: Persons and Politics. Ithaca: Cornell University Press.

Espiritu, Yen Le (2014) Body Counts: the Vietnam war and militarized refuge(es). Oackland, C.A.: University of California Press.

Fioravanti, Andrea (2019) Christina Cattaneo: "I migranti morti in mare? Per gli italiani sono vite di serie B”, 9 May 2019, LinkIesta, https:/www.linkiesta.it/it/article/2019/05/09/cristinacattaneo-migranti-italiani-razzismo/42072/

Gatta, Gianluca (2014) 'Lampedusa, 3 ottobre 2013: Vita, morte, nazione e politica nella gestione delle migrazioni’. Studi Culturali 11(2): 323 - 332.

Goggin, Gerard and Larissa Hjorth (eds) (2009) Mobile Technologies. New York: Routledge.

Hjorth, Larissa and Sarah Pink (2014) 'New visualities and the digital wayfarer:

Reconceptualizing camera phone photography and locative media'. Mobile Media \&

Communication 2(1): 40-57. doi: 10.1177/2050157913505257

Horsti, Karina (2016) 'Imagining Europe's borders: Commemorative art on migrant tragedies', pp. 83-100 in Lynda Mannik (ed) Migration by Boat: Discourses of Trauma, Exclusion and Survival. Oxford: Berghahn.

Horsti, Karina and Klaus Neumann (2017) 'Memorializing mass deaths at the border: Two cases from Canberra (Australia) and Lampedusa (Italy)'. Ethnic and Racial Studies 42(2): 141-158. doi: 10.1080/01419870.2017.1394477

International Organization for Migration (2019) Missing Migrants Project https://missingmigrants.iom.int/region/mediterranean

Kovras, Iosif and Simon Robins (2016) 'Death as the Border: Managing Missing Migrants and Unidentified Bodies at the EU's Mediterranean Frontier'. Political Geography 55: 40-49. 
Madianou, Mirca (2016) 'Ambient co-presence: Transnational family practices in polymedia environments’. Global Networks 16(2): 183-201.

Pink, Sarah; Horst, Heather; Postill, John; Hjorth, Larissa; Lewis, Tania; Tacchi, Jo (2016) Digital Ethnography: Principles and Practice. London: Sage.

Puggioni, Raffaela (2015) 'Border Politics, Right to Life and Acts of Dissensus: Voices from the Lampedusa Borderland'. Third World Quarterly 36(6): 1145-1159.

Ritaine, Évelyne (2015) 'Quand les morts de Lampedusa entrent en politique : damnatio memorice'. Cultures \& Conflits 99-100: 117-142.

Robins, Simon (2019) 'The affective border: missing migrants and the governance of migrant bodies at the European Union's southern frontier'. Journal of Refugee Studies, fey064, https://doi.org/10.1093/jrs/fey064

Robins, Simon (2014) 'Constructing meaning from disappearance: local memorialisation of the missing in Nepal'. International Journal of Conflict and Violence 8(1): $105-118$.

Rygiel, Kim (2016) 'Dying to Live: Migrant Deaths and Citizenship Politics Along European Borders: Transgressions, Disruptions, and Mobilizations'. Citizenship Studies 20(5): 545-560.

Squire, Vicki (2017) 'Governing migration through death in Europe and the US: Identification, burial and the crisis of modern humanism'. European Journal of International Relations 23(3): 513-532.

Stierl, Maurice (2016) 'Contestations in Death - the Role of Grief in Migration Struggles'. Citizenship Studies 20(2): 173-91.

Stümer, Jenny (2018) 'The dead are coming: Border politics and necropower in Europe'. Cultural Politics 14(1): 20-39.

United for Intercultural Action (2019) List of Deaths database, http://www.unitedagainstracism.org/campaigns/refugee-campaign/working-with-the-list-ofdeaths/

Vullo, Amalia (2018) Phone interview with Ilaria Tucci and Karina Horsti, October 7, 2018.

Wilding, Raelene (2018) Families, Intimacy and Globalization: Floating ties. London: Palgrave.

Zagaria, Valentina (2016) 'Vita e morte alla porta d'Europa: riflessioni sulle tome dei morti di frontiera nella provincia di Agrigento'. Intrasformazione 5(1): 80-100. 